\title{
PRINSIP KOMUNIKASI ISLAM TENTANG DIALOG (Kajian Kepustakaan terhadap Komunikasi Interpribadi)
}

\author{
ROSNIAR \\ Program Studi Komunikasi dan Penyiaran Islam \\ Fakultas Ushuluddin dan Dakwah IAIN Bone \\ rosniar@iain-bone.ac.id
}

\begin{abstract}
Dialogue does not always aim to resolve disputes, but rather aims to develop a shared understanding of a complex topic. Dialogue is a form of structured interpersonal communication, relying on full attention, involving all parties to argue and listen actively. Dialogue is different from debate because debate always offers two points of view with the aim of proving the validity or truth of one perspective against another. Therefore, dialogue does not only involve the mind but also the heart because in interactions it has ethical standards in communication and its relationship with the Islamic communication strategy that commands Allah Subehanahu Wata'ala in the Koran. To obtain representative data, a library research approach is used by searching, collecting, reading, and analyzing books, literature, and documents that are relevant to this research problem. The data collected is then analyzed using a scientific approach to Islamic Communication, so that a result is found that reveals that dialogue should be carried out by allowing people to understand the perspectives of others without ignoring a different perspective of oneself. In the form of interpersonal relationships that are bound by topics or themes that can be explored together by thinking objectively based on the principles of Islamic communication, namely qaulan sadidan (true, not lying); qaulan baligha (straightforward, effective); qaulan ma'rufa (kind and polite words); qaulan karima (respect, respect); Qaulan Layina (Gentle); And Qaulan Maysura (Easy to Understand).
\end{abstract}

Keywords: Principles, Islamic Communication, Dialogue, Interpersonal Communication.

\begin{abstract}
Abstrak
Dialog tidak selalu bertujuan untuk menyelesaikan pertengkaran, tetapi lebih bertujuan untuk mengembangkan pemahaman bersama atas sebuah topik yang kompleks. Dialog merupakan bentuk komunikasi interpribadi yang terstruktur, mengandalkan perhatian penuh, melibatkan semua pihak untuk berargumentasi dan mendengarkan secara aktif. Dialog berbeda dengan debat karena debat selalu menawarkan dua titik pandang dengan tujuan untuk membuktikan keabsahan atau kebenaran dari salah satu sudut pandang terhadap yang lain. Oleh karena itu, dalam dialog tidak hanya melibatkan pikiran tetapi juga hati karena dalam interaksi memiliki standar etika dalam berkomunikasi dan hubungannya dengan strategi komunikasi islami yang perintah Allah Subehanahu Wata'ala dalam Al-Quran. Untuk memeroleh data yang representatif, digunakan pendekatan kepustakaan (library research) dengan cara mencari, mengumpulkan, membaca, dan menganalisa buku-buku, literatur, dan dokumen yang ada relevansinya dengan masalah penelitian ini. Data yang dikumpulkan kemudian dianalisis menggunakan pendekatan keilmuan Komunikasi Islam, sehingga ditemukan sebuah hasil yang mengungkapkan bahwa dialog sebaiknya dilakukan dengan memungkinkan orang untuk mengerti sudut pandang orang lain tanpa mengabaikan perspektif diri sendiri yang berbeda. Berupa hubungan interpersonal yang terikat oleh topik atau tema yang dapat
\end{abstract}


dieksplorasi bersama dengan berpikir secara objektif yang berlandaskan pada prinsip komunikasi Islam yaitu qaulan sadidan (benar, tidak dusta); qaulan baligha (lugas, efektif); qaulan ma'rufa (kata-kata yang baik dan sopan); qaulan karima (hormat, respek); Qaulan Layina (Lemah Lembut); Dan Qaulan Maysura (Mudah Dimengerti).

Kata Kunci: Prinsip, Komunikasi Islam, Dialog, Komunikasi Interpribadi.

\section{PENDAHULUAN}

Salah satu keistemewaan umat manusia yang diberikan oleh Allah Subehanahu Wata'ala adalah kemampuan untuk berbicara, sebagai pembeda dengan makhluk ciptaan-Nya yang lain. Mengajarkan manusia untuk mengungkapkan dirinya dan memahamkan orang lain dengan menyampaikan pesan yang jelas. Kemampuan berbicara inilah merupakan esensi dari sebuah dialog. Seperti yang disebutkan dalam QS. Ar-Rahman, 55:1-4. 'Allamahulbayaan, dengan kemampuan berbicara maka hadirlah potensi lain dalam diri manusia yaitu berpikir dan berinteraksi dengan sekitarnya.

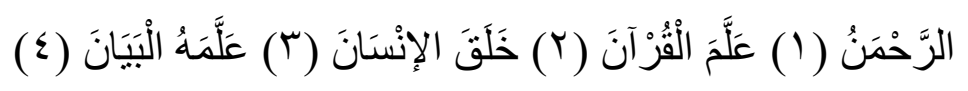

Terjemahnya:

(1). (Allah) yang Maha Pengasih; (2). Yang telah mengajarkan Al-Quran; (3). Dia menciptakan manusia; (4). Mengajarnya pandai berbicara. (QS. Ar-Rahman, 55:1-4). ${ }^{1}$

Manusia hidup berdampingan dengan manusia lainnya sehingga dalam kehidupan sosialnya perlu berinteraksi dengan manusia lain. Dalam konteks komunikasi disebut dengan komunikasi interpersonal, yaitu komunikasi yang berlangsung di antara dua orang atau lebih secara tatap muka. Salah satu bagiannya adalah komunikasi diadik (dyadic communication) yang biasa dilakukan melalui percakapan, wawancara dan dialog.

Keberadaan dialog dalam kehidupan semakin penting jika melihat perkembangan dunia modern yang diwarnai dengan berbagai pertikaian, permusuhan, dan peperangan antar-berbagai kelompok karena kepentingan-kepentingan tertentu. Karena itu, perlu dibangun sikap saling memahami eksistensi masing-masing, meningkatkan kerja sama dan mendekatkan perbedaan yang ada.

Dialog bukan perdebatan atau saling membantah. Dialog adalah kesempatan untuk samasama membingkai masalah secara kolektif, dan semua pihak bersikap independen menyuarakan perspektif mereka terhadap masalah. Ketika individu memiliki perspektif yang berbeda dan

\footnotetext{
${ }^{1}$ Yayasan Wakaf UMI, Al-Quran dan Terjemahnya, (Depok: Sabiq, 2017), h. 531.
} 
melihat masalah secara berbeda, maka dialog dapat digunakan sebagai alat komunikasi yang efektif untuk membantu pihak-pihak yang terlibat memahami titik pandang masing-masing.

Menurut Effendy dialog adalah bentuk komunikasi interpersonal yang menunjukkan terjadinya interaksi. ${ }^{2}$ Mereka yang terlibat dalam komunikasi bentuk ini berfungsi ganda, menjadi pembicara dan pendengar secara bergantian. Dialog merupakan arena tukar pikiran, bukan sekedar mengirim pesan oleh satu pihak dan menerima pesan tersebut di pihak lain. Karena itu masing-masing pihak harus mau memperhatikan dan mendengarkan pandangan pihak lain serta tidak membantahnya.

Dialog harus digunakan jika dua pihak telah berhasil membingkai suatu masalah yang berbeda. Melakukan sebuah percakapan di mana pihak-pihak yang ikut serta berusaha untuk masuk ke dalam suatu hubungan dengan orang lain meskipun ada perbedaan di antara mereka. Dialog yang efektif tercapai apabila para peserta mampu mendengarkan satu sama lain dengan tanpa prasangka, karena dialog memang pada dasarnya dilakukan dengan sikap saling menghormati, saling mengerti, saling percaya, dan saling menerima orang lain.

Hal inilah yang membedakan antara dialog dengan debat. Liliweri menyebutkan bahwa betapa sering orang menyamaratakan dialog dengan debat, padahal kedua konsep ini jelas memiliki substansi yang berbeda. ${ }^{3}$ Perbedaan keduanya bisa dilihat dari contoh pernyataan ini misalnya, dialog adalah kerja kolaboratif, "saya harus terlibat dan bekerja sama untuk mencapai pemahaman bersama". Sementara debat, "saya tidak perlu bekerja sama, saya harus mempertahankan pendapat, karena pendapat saya yang paling benar”.

Bahkan dapat dikatakan bahwa asumsi dialogic encounter merupakan sesuatu yang esensial dalam interaksi manusia. Thomlison menjelaskan lebih jauh bahwa dialogic encounter bukan merupakan suatu metode, tetapi lebih daripada sikap atau orientasi baru terhadap komunikasi karena di dalam komunikasi yang dialogis, masing-masing peserta mempunyai perhatian yang sejati terhadap orang lain tidak sebagai sasaran semata-mata, tetapi sebagai mitra yang sederajat. ${ }^{4}$ Mengapa demikian? Karena komunikasi dapat dikatakan sebagai suatu sarana kebersamaan itu selalu dipertentangkan dengan pemaksaan kehendak, pemanfaatan sumber daya, perwujudan dari interaksi yang tidak jujur untuk mengolah orang-orang dalam berbagai tindakan, dan dialog merupakan jawabannya karena dengan dialog kita membangun kepercayaan, keterbukaan, spontanitas, kepeduliaan, kepekaan, ketulusan dan empati. Dalam banyak hal, dialog merupakan sarana pembentukan hubungan antarpersonal yang ideal. h. 73 .

${ }^{2}$ Onong Uchyana Efendi, Ilmu Komunikasi Teori dan Filsafat Komunikasi, (Bandung: Rosdakarya, 2003),

\footnotetext{
${ }^{3}$ Alo Liliweri, Komunikasi; Serba Ada Serba Makna. (Jakarta: Kencana, 2011), h. 414.
}

${ }^{4}$ Alo Liliweri, Komunikasi; Serba Ada Serba Makna. h. 407-408. 
Seperti apa perintah dialog dalam Islam. Afidah mengutip dari Ibnu Hisyam, as-Shirah anNabawiyyah, dengan memberikan sebuah contoh dialog Nabi Muhammad Sallallahu'alaihi wasallam dengan Abu Al-Walid (Utbah Bin Rabieeah). ${ }^{5}$ Dalam sejarah Islam dialog ini begitu populer, yaitu ketika Utbah, yang mewakili tokoh-tokoh kafir Makkah, menghadap Rasulullah dan menawarkan kepada beliau harta yang melimpah, kehormatan/ketokohan dan kekuasaan, dengan harapan Nabi meninggalkan misi dakwah yang dilakukannya, atau kalau ternyata dengan dakwahnya itu Nabi dalam keadaan kerasukan jin, mereka siap untuk mengobatinnya.

Saat pertama kali Utbah datang dan berkata ingin memberikan beberapa tawaran, Rasulullah mempersilahkannya berbicara terlebih dahulu. "Qul yaa Abal Walid asmae (Katakan hai Abal Walid, saya akan mendengarkannya), demikian kata Rasulullah. Meskipun sesuatu yang ditawarkannya hanya seperti lelucon jika dibanding besarnya tanggung jawab dakwah yang diemban Rasulullah, beliau tetap mendengarkannya sampai selesai dan tidak memotongnya bahkan tidak membantahnya. Baru ketika telah selesai, Rasulullah berkata: "Afaraghta yaa Abal Walid?" (Sudah selesai hai Abal-Walid?).

Setelah diperkenankan, Rasulullah memulainya dengan membacakan ayat-ayat Al-Qur'an dalam QS. Fushshilat. Mendengar itu, Abal Walid yang sebelumnya begitu percaya diri, berubah wajahnya dan terpengaruh dengan bacaan Nabi sampai rekan-rekannya menduga ia telah disihir. Salah satu teladan/contoh yang dilakukan oleh Nabi Muhammad Sallallahu'alaihi wasallam dalam menyampaikan argumentasinya, beliau selalu mendengarkan dan memberikan kesempatan kepada orang yang diajaknya bicara tersebut, beliau tidak membantahnya dan tidak mendebatnya.

Berkaitan dengan riwayat di atas, dalam dialog maka seorang muslim harus berpedoman pada sumber utama Islam, yakni Al-Qur'an dan Sunnah Nabi. Imam Ghazali memberikan batasan tentang pembicaraan (berkomunikasi) yang bermanfaat adalah "bila kita duduk, lalu menceritakan keadaan yang kita alami dalam perjalanan, seperti melihat gunung-gunung dan padang pasir yang tiada dusta di dalamnya." QS. Al-Furqan, 25:63 memerintahkan agar berbicara dengan rendah hati dan mengucapkan kata-kata yang mengandung keselamatan, mengandung prinsip manfaat, terkait pula dengan prinsip relevansi, yaitu menanyakan "apakah pesan yang disampaikan relevan dengan konsep pembicaraan?” dan prinsip dampak, yaitu menanyakan "apakah dampak pesan bagi orang lain?"6

${ }^{5}$ Anis Afidah, Etika Dialog dalam Al-Qur'an (Studi Analisis Term al-Hiwār, al-Jidāl, dan al-Hijāj, Skripsi. Program Studi Tafsir Hadist, Fakultas Ushuluddin dan Humaniora, UIN Walisongo Semarang (2016), h. 77.

6 I.A. Ghazali, Ringkasan Ihya' Ulumuddin. Terjemahan Zeid HuSein al-Hamid, (Jakarta: Pustaka Amani, 2007), h. 375. 
Berdasarkan gambaran di atas jelaslah bahwa Islam memberikan perhatian khusus terhadap pembicaraan, bahkan dipandang salah satu perkara yang akan menyelamatkan manusia, baik di dunia dan di akhirat. Pembicaraan dimaksud adalah pembicaraan yang beretika, sehingga proses dialog bisa berjalan dengan baik serta terjalin hubungan yang harmonis di antara orang yang berdialog.

\section{METODE PENELITIAN}

Penelitian ini menggunakan studi pustaka (library research) yaitu serangkaian kegiatan yang berkenaan dengan metode pengumpulan data pustaka, membaca dan mencatat serta mengolah bahan penelitian. ${ }^{7}$ Oleh karena itu, peneliti mengumpulkan data dan kemudian mengkaji buku-buku ataupun sumber bacaan yang lain yaitu sumber yang memiliki relevansi dengan penelitian ini yaitu prinsip komunikasi Islam tentang dialog dalam konteks komunikasi interpribadi.

Penelitian ini menggunakan pendekatan kualitatif. Menurut Kriyantono penelitian kualitatif bertujuan untuk menjelaskan fenomena sedalam-dalamnya melalui pengumpulan data sedalam-dalamnya. ${ }^{8}$ Sedangkan menurut Moleong, adalah penelitian yang menggunakan pendekatan naturalistik untuk mencari dan menemukan pengertian atau pemahaman tentang fenomena dalam suatu latar yang berkonteks khusus. ${ }^{9}$

Ukuran kualitas sebuah riset terletak pada kesahihan atau validitas data yang dikumpulkan selama riset. Teknik validitas data penelitian ini menggunakan triangulasi data. Dalam penelitian kualitatif, data diperoleh dari berbagai sumber dengan menggunakan teknik pengumpulan data yang bermacam-macam (triangulasi) dan dilakukan secara terus menerus sampai datanya jenuh. ${ }^{10}$ Triangulasi adalah membandingkan atau mengecek ulang derajat kepercayaan suatu informasi yang diperoleh dari sumber yang berbeda. ${ }^{11}$

Teknik analisis data dilakukan dengan cara reduksi data (data reduction), dalam tahap ini peneliti melakukan pemilihan, dan pemusatan perhatian untuk penyederhanaan, abstraksi, dan transformasi data kasar yang diperoleh. Penyajian data (data display), pengembangkan sebuah deskripsi informasi tersusun untuk menarik kesimpulan dan pengambilan tindakan. Penyajian data (display data) dalam bentuk teks naratif. Penarikan kesimpulan dan verifikasi (conclusion

${ }^{7}$ Mestika Zed, Metode Penelitian Kepustakaan, (Jakarta: Yayasan Obor Indonesia, 2008), hal. 3.

\footnotetext{
${ }^{8}$ Rahmat Kriyantono, Teknik Praktis Riset Komunikasi, (Jakarta: Kencana, 2008), hal. 56.

${ }^{9}$ Lexy J. Moleong, Metode Penelitian Kualitatif, (Bandung: Remaja Rosdakarya, 2009), h. 5.

${ }^{10}$ Sugiyono, Memahami Penelitian Kualitatif, (Bandung: Alfabeta, 2014), hlm. 87.

${ }^{11}$ Rahmat Kriyantono, Teknik Praktis Riset Komunikasi, h. 72.
} 
drawing and verification), menarik kesimpulan dan melakukan verifikasi dengan mencari makna setiap gejala yang diperoleh.

\section{HASIL DAN PEMBAHASAN}

\section{Dialog dalam Konteks Komunikasi Interpribadi}

Martin Buber, ahli filsafat yang terkenal, telah mengembangkan dan menaruh perhatian yang sangat besar terhadap dialog. Konsepnya tentang I-Thou dan I-It merupakan satu dari banyak cara yang digunakan untuk menjelaskan beragam jenis dan tipe relasi Interpribadi. Sekurang-kurangnya ada tiga jenis dialog yang ditawarkan oleh Buber, yaitu: Pertama. Dialog yang sejati, di mana relasi sosial yang bersifat mutual itu bertumbuh; Kedua. Dialog teknis, yakni dialog yang mengarahkan para peserta untuk mencapai pemahamanyang objektif; Ketiga. Monolog, yang lebih tertarik pada diri sendiri. ${ }^{12}$

Bubber ingin mengatakan bahwa I-Thou merupakan hubungan yang bersifat dialogis, sementara itu I-It merupakan hubungan yang bersifat monologis. Atas alasan itulah maka Bubber mengakui bahwa setiap hari manusia selalu mengganti-ganti tipe-tipe interaksi untuk mencapai komunikasi yang sukses.

Manusia adalah makhluk yang kompleks, maka hubungan 'saya-engkau' ini memandang bahwa setiap manusia memiliki pengalaman hidup yang penting karenanya perlu dihargai, walaupun pengalaman orang lain itu berbeda dengan pengalaman kita sendiri. Pada hubungan inilah terjadi interaksi dialektis secara terus-menerus guna menghadapi kompleksitas diri sendiri dan kompleksitas orang lain. Namun sering kali manusia tidak memperlakukan orang lain sebagai individu berharga, keadaan ini dinamakan dengan hubungan 'saya-objek' di mana seseorang lebih mengistimewakan dirinya sendiri daripada orang lain.

DeVito menyebutkan bahwa setiap orang dan setiap hubungan adalah unik. Apa yang benar atau berlaku pada sebagian besar orang atau kelompok tertentu belum tentu benar atau berlaku pada diri anda atau hubungan anda. Apa yang benar secara statistik belum tentu benar untuk orang tertentu. ${ }^{13}$ Hubungan antarpribadi merupakan hal yang hidup dan dinamis dan hubungan ini selalu berkembang, tidak pernah statis dan selalu berubah.

Hidup berarti ikut serta dalam dialog: bertanya, memperhatikan dengan saksama, merespon, setuju, dan seterusnya. Dalam dialog ini, seseorang ikut serta secara penuh dan

12 Stephen W. Littlejohn dan Karean A. Foss, Teori Komunikasi: Theories of Human Communication, Terjemahan Muhammad Yusuf Hamdan, (Jakarta: Salemba Humanika, 2008), h. 408.

13 Joseph A DeVito, Komunikasi Interpribadi. Edisi Kelima, Terjemahan oleh Agus Maulana. (Tangerang: Karisma Publishing Group, 2011), h. 250. 
sepanjang hidupnya: dengan matanya, bibirnya, tangannya, jiwanya, semangatnya, dengan seluruh tubuh dan perbuatannya. Dialog dalam kehidupan berisi tentang bagaimana orang hidup bersama dengan orang lain, dialog harus melihat bahwa semua pihak kadang-kadang memberikan kritik dan saran atau bahkan mengalami hubungan yang berantakan. Dengan kata lain, dialog merupakan suatu komunikasi interpersonal yang paling alami yang sering dialami dalam berbagai kegiatan di tengah-tengah masyarakat.

Kita menegosiasikan pemahaman kita dalam interaksi dengan orang lain dalam bentuk dialog. Berdialog tentunya menggunakan kata-kata dan sering diselingi dan disertai dengan pesan-pesan nonverbal. Oleh karenanya, pesan-pesan kita merupakan kombinasi isyarat-isyarat verbal dan nonverbal, dan efektivitasnya tergantung pada bagaimana kedua macam isyarat ini dipadukan.

Dalam dialog, lisan mempunyai peran yang sangat penting dalam hal pembicaraan. Karena pada dasarnya cara berkomunikasi yang efektif di antaranya adalah dengan pemilihan kalimat yang tepat, perkataan yang lembut dan cerdas sehingga tercipta komunikasi efektif yang ditandai dengan pemahaman di antara partisipan komunikasi, diikuti dengan perubahan sikap, pemikiran, dan perilaku. ${ }^{14}$

Pearce menyebutnya dengan speech acts (tindak tutur). Keduanya mendeskripsikan tindak tutur sebagai tindakan-tindakan yang kita lakukan dengan berbicara, termasuk memuji, menghina, berjanji, mengancam, menyatakan, dan bertanya. ${ }^{15}$ Tindak tutur menyampaikan niat pembicara dan mengindikasikan bagaimana komunikasi harus dijalankan. Tindak tutur bukanlah benda, tindak tutur adalah konfigurasi dari logika makna dan tindakan dari percakapan, dan konfigurasi ini dibangun bersama.

Sebagaimana praktiknya dalam kehidupan sehari-hari, dalam strategi komunikasi dikenal teori makrokognitif (karena melihat bagaimana kita menyusun pesan pada level tindakan yang sulit). Salah satunya adalah teori strategi kesopanan. Teori ini menyatakan bahwa dalam kehidupan sehari-hari kita merancang pesan yang dapat melindungi muka sekaligus mencapai tujuan lainnya. Brown dan Levinson percaya bahwa kesopanan sering kali merupakan tujuan karena kesopanan merupakan nilai universal secara kultural. Setiap kebudayaan memiliki derajat yang berbeda dalam hal kebutuhan terhadap kesopanan dan juga cara-cara yang berbeda untuk menjadi sopan, tetapi semua orang memiliki kebutuhan untuk dihargai dan dilindungi. ${ }^{16}$

\footnotetext{
${ }^{14}$ Alex Sobur, Semiotika Komunikasi, (Bandung: Remaja Rosdakarya, 2006), h. 301.

15 Richard West dan Turner Lynn H, Pengantar Teori Komunikasi; Analisis dan Aplikasi. Buku 1. Terjemahan oleh Maria Natalia Damayanti Maer, (Jakarta: Salemba Humanika, 2008) h. 119.

16 Morissan, Teori Komunikasi; Individu Hingga Massa, (Jakarta: Kencana, 2013), h. 170-171.
} 
Memilih perkataan yang baik sesungguhnya menjadi bagian dari upaya kita untuk menghargai orang lain dan diri kita sendiri. Artinya orang lain ketika berkomunikasi dengan kita juga akan mampu menghargai ketika kita juga menghargai mereka. Seringkali manusia tidak dihargai karena dirinya sendiri tidak mampu menghargai orang lain. Namun yang jelas, perintah berbuat baik tidak hanya terbatas pada ucapan, tetapi segala bentuk tindakan (tingkah laku) harus membuat nyaman sekitar.

Brown dan Levinson menyebutnya dengan face needs (kebutuhan wajah). Wajah positif adalah keinginan untuk dihargai dan diakui, untuk disukai dan dihormati, dan kesopanan positif dirancang untuk memenuhi keinginan ini. Menunjukkan perhatian, memberi pujian, dan menggunakan bentuk penyampaian yang terhormat adalah contohnya. Wajah negatif adalah keinginan untuk bebas dari gangguan atau kekacauan, dan kesopanann negatif dirancang untuk melindungi orang lain ketika kebutuhan wajah negatif terancam. Mengakui bahwa anda mengesankan ketika membuat sebuah permintaan merupakan sebuah contoh umum. ${ }^{17}$

Stella Ting-Toomey dan Leeva Chung mengemukakan bahwa facework adalah mengenai strategi verbal dan nonverbal yang kita gunakan untuk memelihara, mempertahankan, atau meningkatkan citra diri sosial kita dan menyerang atau mempertahankan/menyelamatkan citra sosial orang lain. Dengan kata lain, facework berkaitan dengan bagaimana orang membuat apapun yang mereka lakukan konsisten dengan muka mereka. Ting-Toomey menyamakan facework dengan "tarian komunikasi yang berjinjit" (communication dance that tiptoes) antara rasa hormat bagi muka diri sendiri dan muka orang lain. ${ }^{18}$

Menurut Littlejohn dan Foss selalu ada seseorang yang berbicara dengan orang lain, bahkan ketika anda berbicara dengan diri anda. Oleh karena itu, dialog adalah sesuatu yang terjadi dalam sebuah situasi tertentu bagi pelaku dialog tertentu. Inilah yang disebut teori dialogis yang dikemukakan oleh Mikhail Bakhtin. Inti konsepsi Bakhtin tentang dialog adalah ucapan - satuan pertukaran, lisan, atau tulisan antara dua orang. Sebuah ucapan mengacu pada bahasa yang diucapkan pada sebuah konteks. ${ }^{19}$ Ucapan mengandung tema-isi percakapan, sikap pelaku komunikasi terhadap subjek tersebut, dan beberapa tingkat kemampuan reaksi pada bagian orang yang dituju. Selanjutnya pelaku komunikasi mengungkapkan sebuah gagasan dan membuat sebuah penilaian tentang gagasan tersebut, mengantisipasi respon dari orang yang bersangkutan. Pembicara tidak hanya mengantisipasi sudut pandang orang lain dan

17 Stephen W. Littlejohn dan Karean A. Foss, Teori Komunikasi: Theories of Human Communication, h. 183.

18 Richard West dan Turner Lynn H, Pengantar Teori Komunikasi; Analisis dan Aplikasi. Buku 2. Terjemahan oleh Maria Natalia Damayanti Maer, (Jakarta: Salemba Humanika, 2008) h. 163.

19 Stephen W. Littlejohn dan Karean A. Foss, Teori Komunikasi: Theories of Human Communication, h. 300. 
menyesuaikan komunikasinya berdasarkan pada antisipasi tersebut, tetapi orang tersebut juga ikut serta dengan merespon, menilai, dan memulai ucapannya.

Sudut pandang Baxter menyatakan bahwa hubungan terbentuk melalui dialog (relationships are made in dialogue), dialog menentukan bagaimana anda memberi makna atau mendefinisikan hubungan dengan orang lain. Selain itu, dialog memberikan peluang untuk mencapai kesatuan dalam perbedaan (dialogue affords an opportunity to achieve a unity within diversity). ${ }^{20}$

Hal tersebut menandakan bahwa ide mengenai diri anda dan orang lain serta hubungan yang terjalin di antaranya dibangun atau dikonstruksi melalui pembicaraan, pada saat itulah suatu percakapan antara dua orang atau lebih yang memiliki pandangan yang berbeda tentang sebuah masalah terjadi. Agar tidak terjadi hal-hal yang tidak diharapkan, maka diperlukan dialog. Dialog, tujuan utamanya adalah agar setiap pihak dapat memahami pihak lain, sehingga masingmasing dapat memiliki pengetahuan dan wawasan yang luas dan berkembang. Dengan demikian, dialog adalah sebuah jaringan hubungan dengan orang lain yang kompleks. Dialog merepresentasikan sebuah subjek bahasan kontekstual yang berlanjut dan berkembang yang memperbesar definisi konstan dari pelaku dalam dialog.

Sebuah dialog dapat membuat para pesertanya menyamakan visi misi subjektif mereka dengan tujuan untuk membentuk posisi bersama atau membangun bahasa yang seragam. Namun yang paling utama di antara semua itu adalah bahwa setiap pihak yang terlibat dialog mampu mengaktualisasikan diri dan mengorganisasikan pemikiran-pemikiran dalam wilayah keberagaman. Perbedaan yang majemuk inilah yang membuat peserta dialog cenderung dapat saling memahami dan membuat mereka yang berbeda pendapat dapat hidup bersama.

\section{Prinsip Komunikasi Islam tentang Dialog}

Meskipun Al-Qur'an secara spesifik tidak membicarakan masalah dialog, namun jika diteliti ada banyak ayat yang memberikan gambaran umum prinsip-prinsip dialog dalam konteks perintah dan juga larangan. Kata yang baik dan diucapkan dengan lemah lembut merupakan cara dalam berdialog dengan cara yang terbaik (billati hiya akhsan) adalah salah satu dialog yang beretika yang memiliki prinsip untuk memerintahkan umat muslim untuk berdialog dengan cara lemah lembut, karena hal itu akan membuat suasana dialog berlangsung tenang dan khidmat, jauh dari luapan emosi seperti halnya jika digunakan kata-kata keras dan kotor yang menyinggung perasaan.

20 Morissan, Teori Komunikasi; Individu Hingga Massa, h. 311-312. 


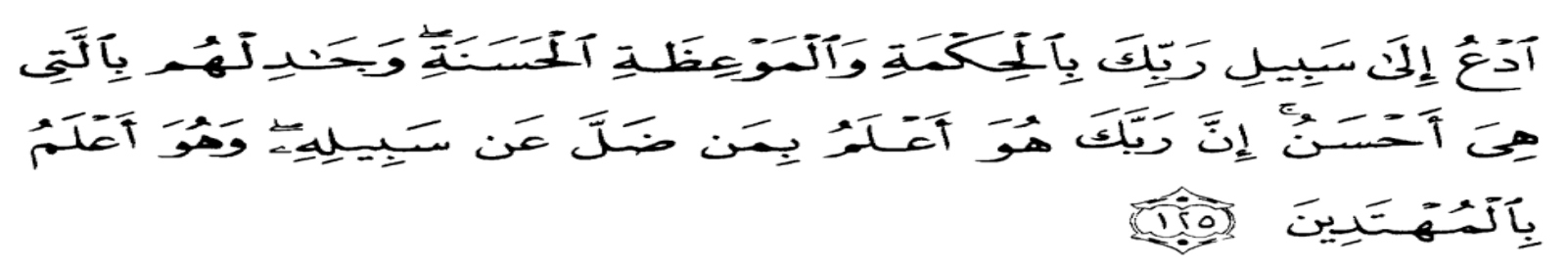

Terjemahnya:

"Serulah (manusia) kepada jalan Tuhanmu dengan hikmah dan pelajaran yang baik dan bantahlah mereka dengan cara yang baik. Sesungguhnya Tuhanmu Dialah yang lebih mengetahui tentang siapa yang tersesat dari jalan-Nya dan Dialah yang lebih mengetahui orang-orang yang mendapat petunjuk". (QS. An-Nahl, 16:125). ${ }^{21}$

Menurut Quraish Shihab, ayat ini dipahami oleh di antara ulama sebagai penjelasan terhadap tiga macam metode dalam berdialog supaya dialog tersebut bisa tepat sasaran. Terhadap cendekiawan yang memilki pengetahuan tinggi diperintahkan menyampaikan dialog maupun berdebat dengan cara hikmah, yakni berdialog dengan kata-kata bijak sesuai dengan tingkat kepandaian mereka. Terhadap kaum awam diperintahkan untuk menerapkan mauidzah, yakni memberikan nasihat dan perumpamaan yang menyentuh jiwa yang sesuai dengan taraf pengetahuan mereka yang sederhana. Sedang terhadap Ahl-Kitab dan penganut agama-agama lain yang diperintahkan adalah jidal/perdebatan dengan cara yang terbaik, yaitu dengan logika dan retorika yang halus, lepas dari kekerasan dan umpatan. ${ }^{22}$

Sebagai bagian dari komunikasi, dialog dalam strategi komunikasi islami baik verbal maupun nonverbal harus sesuai yang diajarkan Allah Subehanahu Wata'ala dalam Al-Quran. Apapun yang dilakukan harus didasari oleh semangat keimanan, yakni sebagai bentuk ibadah kita kepada Allah Subhanahu Wata'ala. Prinsip komunikasi Islam tersebut adalah: qaulan sadidan (benar, tidak dusta); qaulan baligha (lugas, efektif); qaulan ma'rufa (kata-kata yang baik dan sopan); qaulan karima (hormat, respek); qaulan layina (lemah lembut); dan qaulan maysura (mudah dimengerti). ${ }^{23}$

Qaulan sadidan. Adalah seorang komunikator harus menyampaikan perkataan yang benar dan wajib menghindari dusta. Prinsip kepercayaan dapat membangun suasana komunikasi yang kondusif dalam mencapai komunikasi yang efektif dan efisien (QS. An-Nisaa', 4:9; QS. AlAhzab, 33:70). Perkataan benar di sini mencakup substansi isi dan redaksi tata bahasa pesan.

Qaulan baligha. Dimaknai dengan menjalankan komunikasi secara lugas, tepat, fasih, jelas dan tidak berbelit-belit sehingga dapat berbekas pada hati komunikan untuk pada akhirnya

\footnotetext{
${ }^{21}$ Yayasan Wakaf UMI, Al-Quran dan Terjemahnya.

22 M. Quraish Shihab, Tafsir Al-Misbah; Pesan, Kesan, dan Keserasian Al-Quran, (Jakarta: Lentera Hati, 2001), h. 774-775.

${ }^{23}$ Rachmat Kriyantono, Pengantar Lengkap Ilmu Komunikasi: Filsafat dan Etika Ilmunya serta Perspektif Islam. (Jakarta: Prenadamedia Group, 2019), h. 363.
} 
terpersuasi. Prinsip ini menekankan pada cara persuasif dalam berkomunikasi (QS. An-Nisaa', 4:63; QS. Ibrahim, 14:4). Perkataan yang berbekas pada jiwa juga harus dikembangkan dengan menimbang beberapa faktor yaitu, frame of reference dan field of experience dari komunikan.

Qaulan ma'rufa. Prinsip komunikasi ini merupakan jalan tengah antara komunikasi dalam high context culture dan low context culture. Qaulan ma'rufa mempunyai arti sebagai perkataan yang baik, ungkapan yang pantas, santun, dan tidak menyakitkan atau menyinggung perasaan. Ma'rufa adalah perkataan yang indah dan tidak mengandung unsur sindiran yang dapat menyinggung perasaan orang lain. Orientasi prinsip ini mengacu kepada upaya interaksi yang selalu mendatangkan manfaat dan menimbulkan kebaikan (QS. An-Nissa', 4:5; QS, Al-Baqarah, 2:83, QS. Al-Baqarah, 2:253; QS. Al-Baqarah, 2:263; QS. Al-Ahzab, 33:32).

Qaulan karima. Di dalamnya mengandung perkataan yang mulia dan disampaikan dengan penuh hormat agar dapat menjalin relasi dan hubungan baik (QS. Al-Israa', 17:23; QS. Annisaa', 4:148; QS. Al-Hujurat, 49:11).

Qaulan layina. Prinsip komunikasi ini memberi pelajaran kepada umat manusia untuk selalu respek kepada siapapun lawan bicara kita, termasuk orang yang telah menzalimi kita ( $Q S$. Thaahaa, 20:44; QS. Luqman, 31:19; QS. Al-Hujurat, 49:2). Komunikator dituntut berbicara dengan kata yang lemah lembut, suara yang enak didengar, sikap yang bersahabat, dan perilaku yang menyenangkan dalam menyampaikan pesan-pesan kebaikan. Kata-kata lemah lembut ini mencakup pelarangan intonasi atau nada yang keras atau tinggi dan kata-kata kotor yang membuat komunikator dipersepsi tidak bersahabat, merendahkan dan dianggap penuh emosi negatif.

Qaulan maysura. Mengacu kepada sebuah perkataan yang mudah dicerna, mudah dimengerti, dan gampang dipahami oleh khalayak. Prinsip ini mengajarkan nilai keharmonisan dalam menjalin suatu hubungan sosial (QS. Al-Israa', 17:28).

Untuk mendapatkan nilai yang tinggi dari sebuah dialog, Harb mengungkapkan bahwa salah satu pihak yang terlibat tidak mungkin untuk menghapus pandangan-pandangannya sendiri guna mendengarkan pandangan orang lain. Namun yang paling mungkin terjadi adalah penghindaran diri seseorang untuk menempatkan diri pada posisi yang berlawanan dengan lawan dialognya. ${ }^{24}$ Dari sini dapat dipahami bahwa tujuan dari setiap dialog yang sebenarnya adalah penyadaran masing-masing piha pada esensi dan identitas dirinya dalam bentuk yang fleksibel dan terbuka dengan sebuah kenyataan bahwa di balik kepercayaan yang dimilikinya terdapat

${ }^{24}$ Ali Harb, Nalar Kritis Islam Kontemporer; Kritik dan Dialog, (Jogjakarta: IRCiSoD, 2012), h. 354. 
sebuah kepercayaan yang bisa jadi berbeda, dari sinilah manusia bisa mengekspresikan dirinya, menangkap hakikatnya, dan membangun potensi yang dimilikinya.

\section{PENUTUP}

Manusia diberikan potensi oleh Allah berupa diajarinya pandai berbicara, berbahasa, berpikir, mengolah dan mengungkapkan makna dari stimulus sense organs (indra) sehingga bisa saling mengenal dan berinteraksi dengan orang lain di luar dari dirinya. Penggunaan tindak tutur (berbicara) hendaknya menyampaikan niat pembicara dan mengindikasikan bagaimana komunikasi harus dijalankan. Tindak tutur bukanlah benda, tindak tutur adalah konfigurasi dari logika makna dan tindakan dari percakapan, dan konfigurasi ini dibangun bersama. Pembicaraan dimaksud adalah pembicaraan yang beretika, sehingga proses dialog bisa berjalan dengan baik serta terjalin hubungan yang harmonis di antara orang yang berdialog. Walaupun pada kenyataannya banyak di antara kita menyamakan antara dialog dan debat, padahal keduanya memiliki konsep yang berbeda. Debat mengandung pemaknaan yang negatif, berbeda dengan dialog. Melalui proses dialog kita membangun kepercayaan, keterbukaan, spontanitas, kepeduliaan, kepekaan, ketulusan dan empati. Oleh karena itu, dalam banyak hal dialog merupakan sarana pembentukan hubungan antarpersonal yang ideal. Seperti yang ditawarkan dalam Islam berupa sebuah konsep komunikasi islami yang bisa diterapkan dalam berdialog baik verbal maupun nonverbal, prinsip komunikasi islami tersebut adalah: qaulan sadidan (benar, tidak dusta); qaulan baligha (lugas, efektif); qaulan ma'rufa (kata-kata yang baik dan sopan); qaulan karima (hormat, respek); qaulan layina (lemah lembut); dan qaulan maysura (mudah dimengerti). Demikianlan yang diteladankan oleh Rasulullah, dalam menyampaikan argumentasinya, beliau selalu mendengarkan dan memberikan kesempatan kepada orang yang diajaknya berbicara, beliau tidak membantahnya dan tidak mendebatnya.

\section{DAFTAR PUSTAKA}

DeVito, Joseph A. (2011). Komunikasi Interpribadi. Edisi Kelima, Terjemahan olehAgus Maulana. Tangerang: Karisma Publishing Group.

Effendy, Onong Uchyana. (2003). Ilmu Komunikasi: Teori dan Filsafat Komunikasi. Bandung: Rosdakarya.

Harb, Ali. (2012). Nalar Kritis Islam Kontemporer; Kritik dan Dialog. Jogjakarta: IRCiSoD.

Kementerian Agama RI. Al-qur'an dan Terjemahnya. Solo: PT. Tiga Serangkai Pustaka Mandiri. 2016. 
Kriyantono, Rachmat. (2019). Pengantar Lengkap Ilmu Komunikasi: Filsafat dan Etika Ilmunya serta Perspektif Islam. Jakarta: Prenadamedia Group.

Kriyantono, Rachmat. (2008). Teknik Praktis Riset Komunikasi. Jakarta: Kencana.

Liliweri, Alo. (2011). Komunikasi; Serba Ada Serba Makna. Jakarta: Kencana.

Littlejohn, Stephen W. Foss, Karean A. (2008). Teori Komunikasi: Theories of Human Communication. Edisi 9. Terjemahan oleh Muhammad Yusuf Hamdan. 2011. Jakarta: Salemba Humanika.

Moleong, Lexy J. (2009). Metodologi Penelitian Kualitatif. Remaja Rosdakarya: Bandung.

Morissan, (2013). Teori Komunikasi; Individu Hingga Massa. Jakarta: Kencana.

Shihab, M. Quraish. (2001). Tafsir Al-Misbah: Pesan Kesan, dan Keserasian Al-Qur'an. Jakarta: Lentera Hati.

Sobur, Alex. (2006). Semiotika Komunikasi. Bandung: Remaja Rosdakarya.

Sugiyono. (2014). Metmahami Penelitian Kualitatif. Alfabeta: Bandung.

West, Richard dan Lynn H. Turner. (2008). Pengantar Teori Komunikasi; Analisis dan Aplikasi. Buku 1. Terjemahan oleh Maria Natalia Damayanti Maer. Jakarta: Salemba Humanika.

West, Richard dan Lynn H. Turner. (2008). Pengantar Teori Komunikasi; Analisis dan Aplikasi. Buku 2. Terjemahan oleh Maria Natalia Damayanti Maer. Jakarta: Salemba Humanika.

Zed, Mestika.(2008). Metode Penelitian Kepustakaan . Jakarta: Yayasan Obor Indonesia. 